\title{
Investigation of material effects on the passenger car's frame structures in case of collision by Ansys LS-DYNA
}

- Dr. Nguyen Khac Huan

Engineering infantry institute

(Manuscript Received on July 13th, 2015; Manuscript Revised October 16th, 2015)

\section{ABSTRACT}

This paper evaluated the effect of auto framing materials to passenger in collisions by Ansys LS-DYNA simulation software and analysis data by Hyperview software. Process simulation helps authors problem research, survey the feasibility of replacing traditional steel materials in the automotive

Key words: SAMCO-BT3, Ansys LS-DYNA, Solidworks, Hyperview, Composite carbon fiber

\section{INTRODUCTION}

Reduced self-weight of cars and increased passive safety are two important factors when designing automobile frames, shell. During the design process, typically some parts anticollision on cars will be made from synthetic resin to absorb energy. Also partial skeleton structure is also designed to be able to absorb the highest energy is intended to increase the reliability and safety of people and vehicles.

The examination of the anti-collision or safety for people and vehicles are evaluated by analyzing the collision process. Impact assessment process is usually done under the following methods:

- Experiment;

- Simulation the impact of the software. manufacturing industry in Vietnam by carbon fiber composite materials. In addition, the simulation also allows the author to easily change the contact angle, the velocity of impact on a flexible, easy to achieve high economic efficiency during the actual test.
The first selection method with the accuracy and reliability but high cost and implementation process is extremely complex, so not suitable for the current conditions in Vietnam. The application of simulation software collision between two cars to solve the problems of reliability frame, shell and passive safety has brought high accuracy while reducing costs and time of implementation experience. To gradually develop mandatory standards applied to the passenger car's frame structures design, manufacturing and assembly in Vietnam, including taking into account the requirements for structural strength, the material of the frame, shell self protection when the collision occurs. Therefore in this paper, the authors use the LS- 
DYNA ANSYS software and analysis data software on Hyperview to determine the influence of framing materials, to passenger cars bone collisions to determine Bumpers possibility of framing materials, peel through the safety standards of the European people.

\section{FINITE ELEMENT MODELING AND SAFETY STANDARDS FOR COLLISION}

Problem analysis techniques collision dynamics instant by simulation in ANSYS is used to determine the response of structures under the influence of time-dependent loads. We can use this type of analysis to determine the displacements, deformation, stress and timevarying forces. Simulations provide a detailed physical phenomena occurring in the structure of the model since it enables the engineers can adjust the texture before finalizing the design to put into production.

Collision simulation process is performed using software finite element simulation. A finite element model was designed and entered into LSDYNA ANSYS with the boundary conditions, loads and element type defined conditions close to the actual collision.

\subsection{Finite element models}

The SAMCO-BT3 and passenger car's frame structures model designed in SolidWorks (Figure 1) * IGES file is exported, then imported into the software Hypermesh to build finite element. By using the meshing method automesh on each array of car's frame structures (type SHELL element 163), we obtain a finite element model (Figure 2)

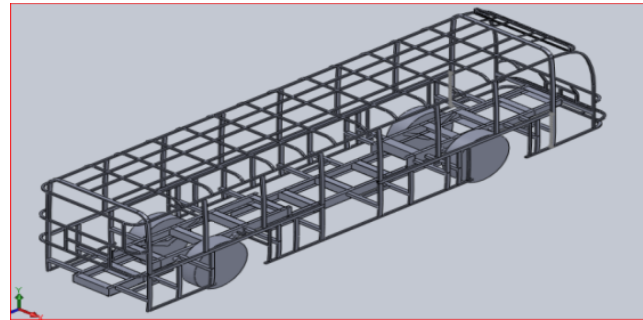

Figure 1. Geometric model passenger car

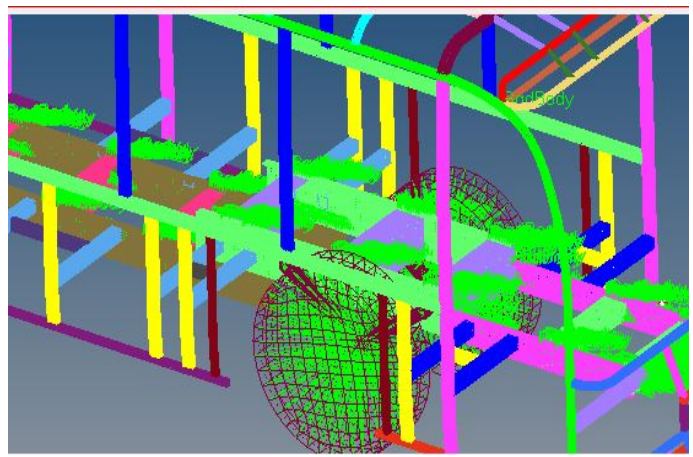

Figure 2. Finite element models

\subsection{HIC standards, safety SI for human when the collision}

This is the international standard for assessing the safety of passengers when automobile to the force of impact. Under this standard, the limits of tolerance of people is considered a function of time with the maximum impact force. FMVSS 208 safety standards of the US [3] defined as follows [7]:

Standard head injury HIC, limited in 1000:

$H I C=\left[\frac{1}{t_{2}-t_{1}} \int_{\mathrm{t}_{1}}^{\mathrm{t}_{2}} \frac{b_{\text {head }}}{g} d t\right]^{2,5} \cdot\left(t_{2}-t_{1}\right)$

Which: $b_{\text {head }}$ : the largest accelerator in head;

t: time impact collision.

\section{Trang 66}


The HIC limit is 1000, while the HIC from 1500 to 2000 , brain severe injury resulting in death

Standard chest injury SI, SI limit is 1000:

$$
S I=\int_{0}^{t}\left(\frac{b_{\text {chest }}}{g}\right)^{2,5} d t
$$

Which: $b_{\text {chest }}$ : the maximum acceleration in the chest;

t: time impact collision.

This limitation is based on biomechanical studies that chest can withstand $60 \mathrm{~g}$ acceleration of $3 \mathrm{~ms}$ without injury, the degree of compression is limited 3inches chest.

\section{SIMULATION}

\begin{tabular}{|c|c|c|c|}
\hline \multicolumn{4}{|c|}{ Table 1 The simulation case } \\
\hline \multirow[t]{2}{*}{ TT } & \multicolumn{2}{|r|}{ Conditions of collision } & \multirow{2}{*}{$\begin{array}{l}\text { Simulation } \\
\text { code }\end{array}$} \\
\hline & $\begin{array}{l}\text { Angle of } \\
\text { collision }\end{array}$ & $\begin{array}{l}\text { Speed (V1: car } \\
\text { collision, } \\
\text { V0: collison) }\end{array}$ & \\
\hline 1 & $90^{\circ}$ & $\mathrm{V}_{1}=15 \mathrm{~km} / \mathrm{h}, \mathrm{V}_{0}=0$ & M1 \\
\hline 2 & $90^{0}$ & $\mathrm{~V}_{1}=20 \mathrm{~km} / \mathrm{h}, \mathrm{V}_{0}=10$ & M2 \\
\hline 3 & $27^{0}$ & $\mathrm{~V}_{1}=20 \mathrm{~km} / \mathrm{h}, \mathrm{V}_{0}=10$ & M3 \\
\hline 4 & $43^{0}$ & $\mathrm{~V}_{1}=48 \mathrm{~km} / \mathrm{h}, \mathrm{V}_{0}=10$ & M4 \\
\hline
\end{tabular}

The author simulated side collision between the same two cars with the velocity and impact angle different. The SAMCO-BT3 and passenger car's frame structures is CT3 steel material, then replaced respectively by composite materials with similar conditions (table 1) [5]. The load placed on the vehicle model is kinetic energy collision of car collisions $T=\frac{1}{2} m V^{2}$ [4], have varying value depending on the method, direction and magnitude of the initial velocity vehicle collisions. The magnitude of the collision velocity decreases from $\mathrm{V}=\mathrm{V} 0$ (initial velocity) until $\mathrm{V}=0$ (velocity end collisions) during analysis is 0,1 seconds collision. During this time we divided into 100 steps, so the increment of time is 0,001 seconds. In each step of the program will record the results.

\section{RESULTS AND EVALUATION}

Simulations in the case in (Table 1) with frame material, frame then replaced with composite materials we obtain the results shown in Section 4.1; 4.2. Some figure collision in case M1, shown in Figure 3, 4

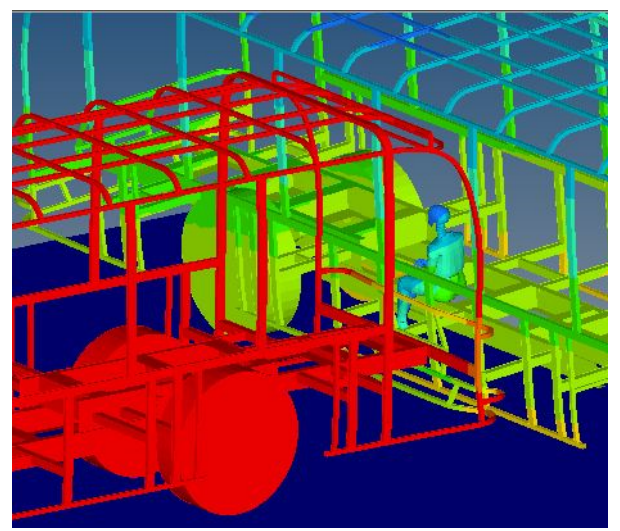

Figure 3. Chassis with steel materials

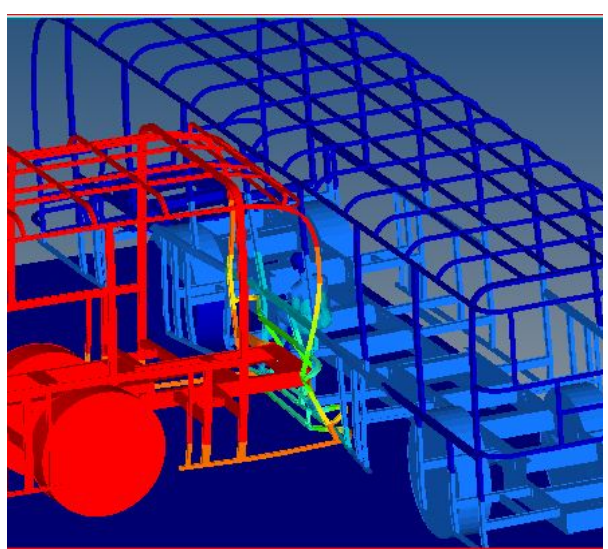

Figure 4. Chassis with composite materials

Results of simulation

Button 137 681: on top of passenger

Button 347 278: on the passenger's chest

Button 349 295: on the lap of passengers

The obtained results are as follows:

Among them : the blue line graph in case M1 : red line graph of cases M2 : green line graph in case M3 : light purple line graph in case M4 
4.1 Acceleration in the survey button when the vehicle using steel materials

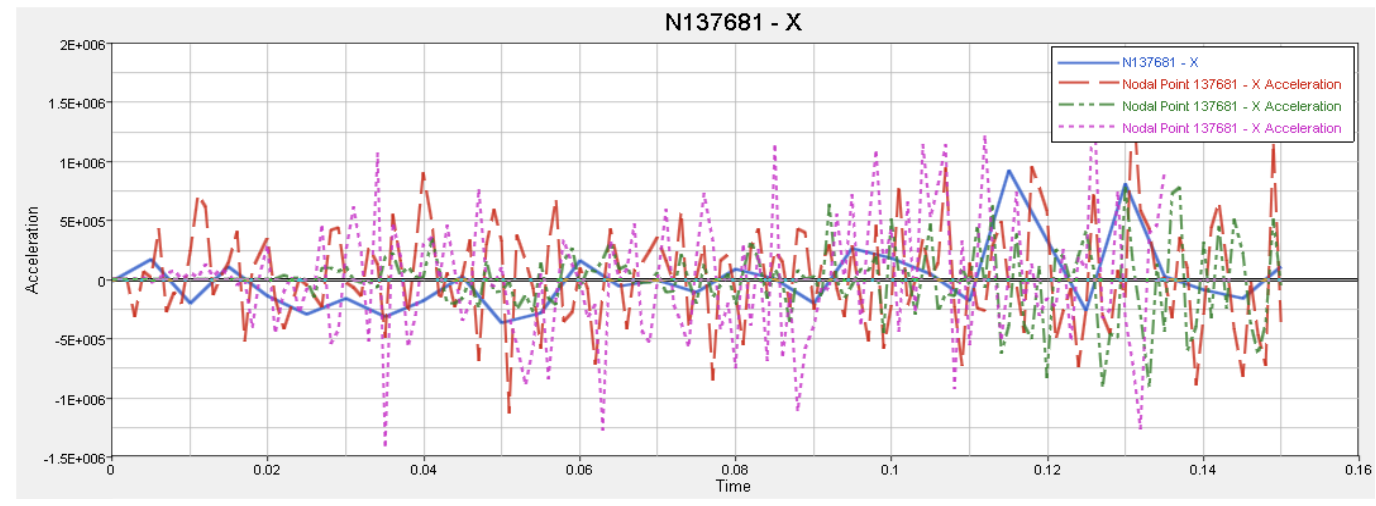

Figure 5. Acceleration at node 137681

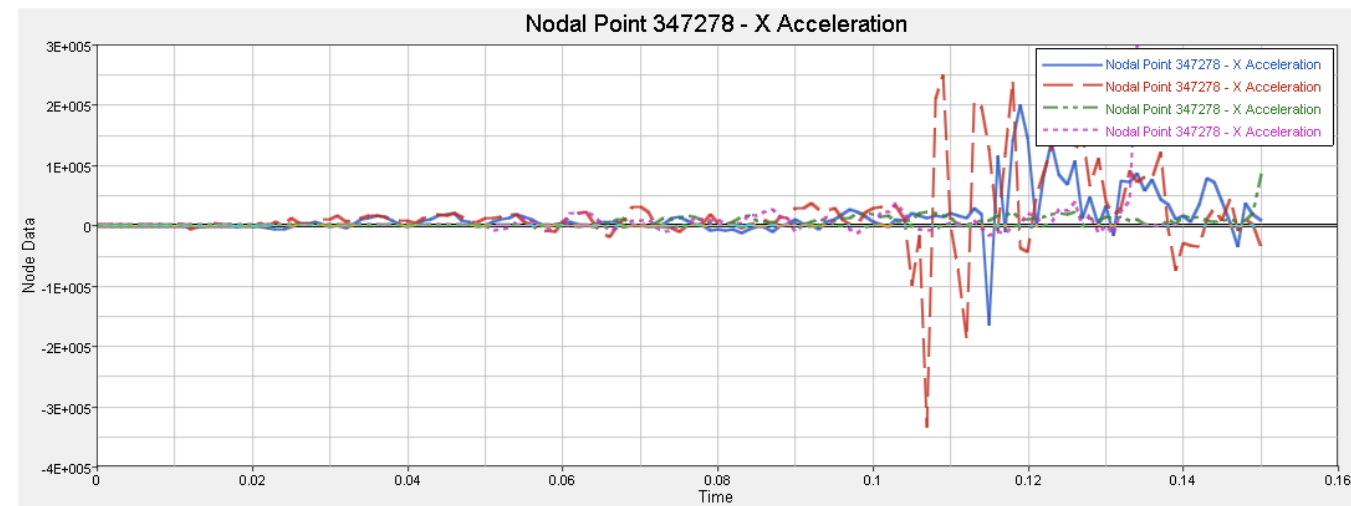

Figure 6. Acceleration at node 347278

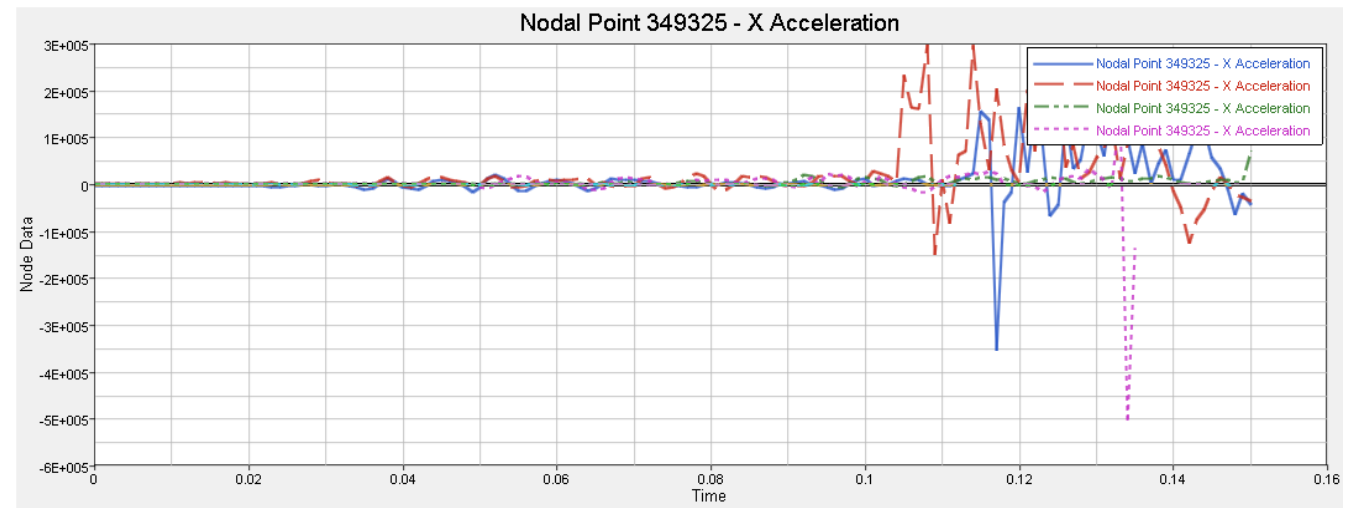

Figure 7. Acceleration at node 349325

\section{Trang68}


4.2 Acceleration in the survey button when car use composite materials

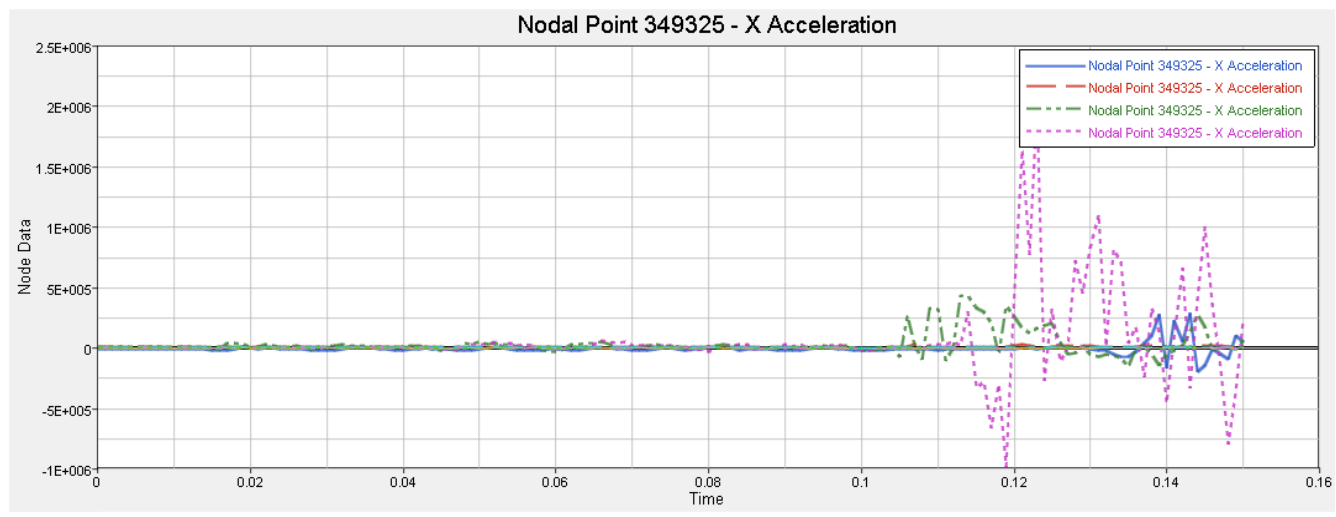

Figure 8. Acceleration at node 137681 composite

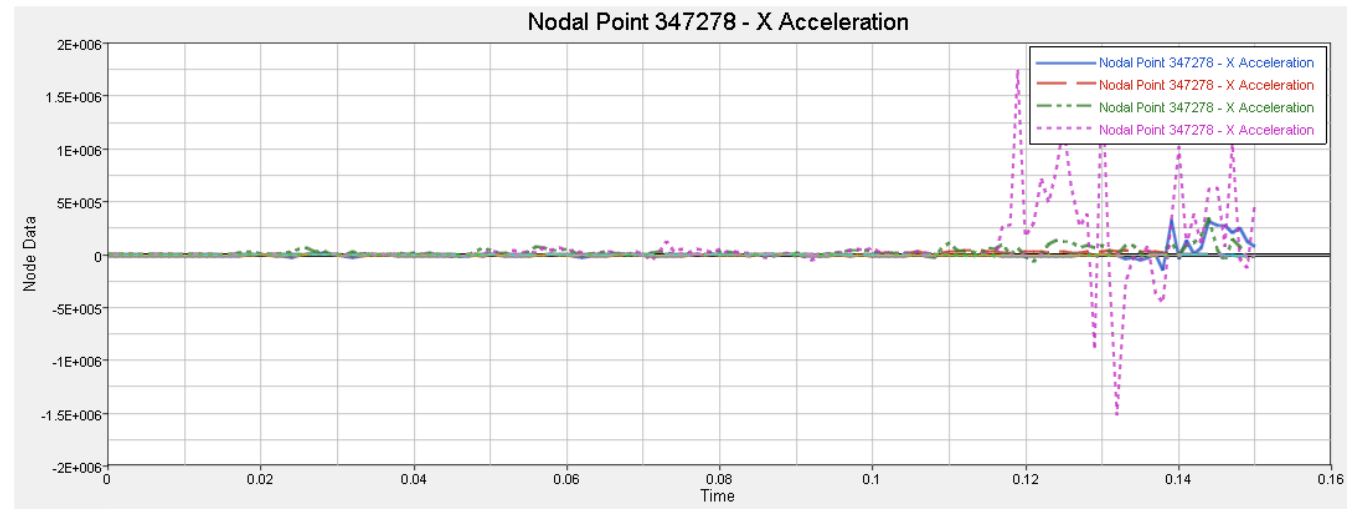

Figure 9. Acceleration at node 347278 composite

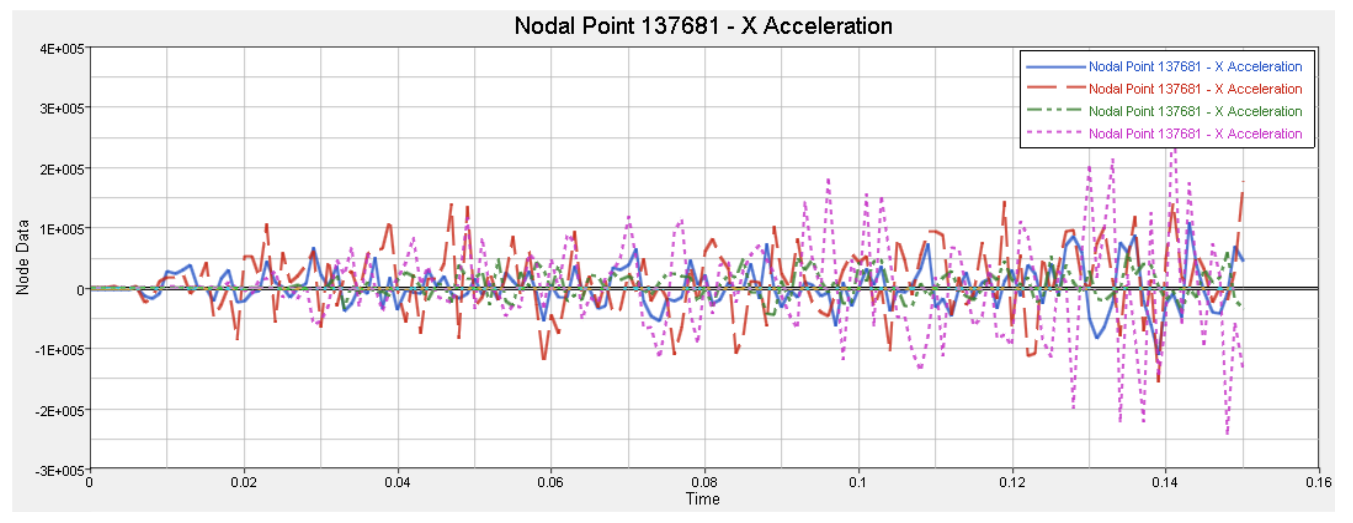

Figure 10. Acceleration at node 349325 composite 
The results were as standard and standard HIC SI

\begin{tabular}{|c|c|c|c|c|}
\hline Case & \multicolumn{2}{|c|}{ Standard HIC } & \multicolumn{2}{c|}{ Standard SI } \\
\hline Materials & Steel & Composite & Steel & Composite \\
\hline M1 & 1048.17 & 788.44 & 1056.68 & 869.57 \\
\hline M2 & 845.33 & 511.82 & 684.75 & 625.83 \\
\hline M3 & 759.92 & 378.49 & 649.55 & 416.14 \\
\hline M4 & 3108.22 & 1063.28 & 3959.33 & 1015.64 \\
\hline
\end{tabular}

According to the timeline the collision to passengers using carbon fiber composite materials have greatly reduced compared to vehicles using steel materials.

The impact force is reduced due to the energy absorption of carbon fiber composite materials.

\section{CONCLUSION}

From the chart we see time acceleration affected passengers collided when replaced with composite materials greatly reduced.
The HIC value standard, SI showed the car using carbon fiber composite materials are always lower than carbon steel materials.

Energy absorption capacity of carbon fiber composite materials is very high so it reduces injury collisions.

From the above results show that use of carbon fiber composite materials in industrial production for passenger cars chassis because it features very good impact reduction.

\section{Trang 70}




\section{Nghiên cứu ảnh hưởng của vật liệu đến kết cấu khung xe con trong trường hợp xảy ra va đâm bằng Ansys LS-DYNA}

\section{- Nguyễn Khắc Huân}

Viện Kỹ thuật Công Binh, Việt Nam

\section{TÓM TÁT}

Bài báo bày đánh giá ảnh hưởng của vật liệu khung xe con trong trường hợp va đâm bằng phần mềm mô phỏng ANSYS LSDYNA và phân tích dũ̃ liệu bằng Hyperview. Quá trình mô phỏng giúp giải bài toán, khảo sát tính khả thi trong việc thay thế vật liệu

thép thông thường sử dụng làm khung ô tô bằng vật liệu sợi carbon composite. Ngoài ra, quá trình mô phỏng cũng cho phép dụ đoán sự thay đổi của góc tiếp xúc, vận tốc va chạm phức tạp nhằm đạt hiệu quả kinh tế cao trong quá trình thử nghiệm thực tế.

Từ khóa: SAMCO-BT3, Ansys LS-DYNA, Solidworks, Hyperview, sợi composite carbon

\section{REFERENCES}

[1]. Chu Quốc Thắng (1997), "Finite element method", Publishers of scientific and technical, Hà Nội

[2]. Nguyễn Văn Phái, Trương Tích Thiện, Nguyễn Tường Long, Nguyễn Định Giang (2003), "Solving Mechanical engineering using ANSYS program", Publishers of scientific and technical, Hà Nội.

[3]. Dieter Anselm (2000), "The Passenger Car Body", Allianz Center for Technology Ismaning, Munich, Germany

[4]. W.J.Stronge (2000), "Impact Mechanics", Cambridge University Press, United Kingdom.
[5]. Waseem Sarwar and Nasir Hayat, "Crash Simulation and Analysis of a Car Body Using ANSYS LS- DYNA, "Failure of engineering materials and structures, code 09, 2007, pp. 65-72...

[6]. Yucheng Liu, "Impact Experimental Analysis and Com-puter Simulation," Department of Mechanical Engineer-ing, University of Louisville.

[7]. William T.Hollowell," Updated review of potential test procedures for FMVSS No.208”, Office Vehicle Safety Research, 1999. 